UDK 78:811.163.6’373.46

Izvorni znanstveni rad

Rukopis primljen 17. VII. 2018.

Prihvaćen za tisak 13. XI. 2018.

\title{
Lorena Mihelač
}

ŠC Novo mesto \& IPS Jožef Štefan

lorena.mihelac@sc-nm.si

\section{Jelena Panić Grazio}

Radio-Television of Slovenia

jelena.grazio@rtvslo.si

\section{Leon Stefanija}

Faculty of Arts

University of Ljubljana

leon.stefanija@ff.uni-lj.si

\section{AN ANALYSIS OF THE SLOVENIAN TERMINOLOGY OF MUSICAL FORMS}

The article presents the results of the analysis of the use of basic Slovenian music terms used in writing about musical structure. Since this terminology includes a large number of terms, we have decided to limit the analysis of basic terms to the following ones: tone, note, motif, figure, melody and musical form. For the purposes of research, we have created a one-language corpus on www.sketchengine.co.uk, which contains graduate, masters ${ }^{6}$ and doctoral theses dealing with music analysis and several textbooks dealing with musical forms. Such a modern corpus approach makes it easier to search terms and their meanings, which ultimately leads to interesting results on how to use certain terms.

\section{Introduction}

"We model the world by the aid of concepts and concept systems." (Anita Nuopponen) We live in the world of concepts (Mikkonen 2004). Concepts are linked with conceptualization and understanding, which are both related to knowledge. Knowledge manifests itself in forms of civilization and culture (Dépelteau and Saviola Landini 2013). Both knowledge and concepts are communicated mainly by language in a society (Schomaker and Zaheer 2014). Therefore, language is the lifeblood of concepts 
and knowledge (Boden 1994: 8; Mikkonen 2004). The understanding of knowledge and language changes all the time and in a certain period new concepts are created and also new ways to express these concepts (Pederson and Nuyts 1997).

In reality, these changes are very complex, as the possibility to create new concepts and combinations of concepts by the aid of language is "infinite times infinity" (Mikkonen 2004), nevertheless not all the imaginable language-related concepts and conceptual ideas are accepted in the "cognisphere".

The Slovenian language is no exception. Over the centuries, it has been constantly changing and so has, due to various linguistic or pragmatic reasons, the Slovenian musical terminology. The fact that this terminology has changed over the centuries while changing the style, sound material, and implementation practice, means that a certain terminology has had more or less validity in a certain historical period.

In our research work, we are exploring various evolvements in the Slovenian musical terminology limiting ourselves to the terminology of musical forms. Since this terminology includes a considerable number of terms, we have decided to limit ourselves to the analysis of the basic musical terms: note, tone, motif, figure, melody and musical form. ${ }^{2}$ This research work is a preliminary study to track the different meanings to the same words and to explore to which extent the available dictionaries can help in tracking the evolution of these terms.

Our paper is organized as follows: in $\S 2$, a short overview of the contributions related to the Slovenian musical terminology is given. It is followed by the presentation of basic information about the corpus, methodology and research tools in $\S 3$ and it focuses on the basic musical terms in $\S 4$. Conclusions and future work are provided in $\S 5$.

\section{Previous contributions to the Slovenian musical terminology}

So far, there have been relatively few commentaries, discussions or research works on the Slovenian musical terminology. In the section below scientific pub-

\footnotetext{
The "cognisphere" is metaphorically defined by Mikkonen as "interrelations and connections of reality/ truth, conceptualization/understanding, knowledge, language, civilization/culture."

2 The translation of the Slovenian terms into English language is proposed by the authors.
} 
lications and up-to-date dictionaries related to the Slovenian musical terminology are presented.

\subsection{Scientific publications}

The first comments and discussions that touched upon the problem of standardizing the musical expression date back to the second and third decade of the previous century. Particularly important is the article in two parts by Marko Bajuk, published in the journal Pevec in 1926 (Bajuk 1926). In the last thirty years, the same issues have been addressed in the ethno-musicological and musicalpedagogical framework (Omerzel Mirit 1999, Vospernik 1995), while the most extensive and musicologically most important contributions are several articles and the doctoral thesis by Jelena Panić Grazio. ${ }^{3}$

\subsection{Dictionaries}

Dictionaries in which musical expressions/terms are collected were already created in the past (Sancin 1933, Škerjanc 1962, Homer 1994, Vrbančič 2010). An example is the Laško-Slovene-German musical dictionary of the Slovenian writer and musician of the Czech genus Vojteh Hybáš, published in 1914 at the Katoliška tiskarna in Ljubljana, and the Musical vocabulary Dušan Sancin, printed at the Celje Mohor Company in 1933. Their weaknesses are mainly reflected with limited scope (Hybáškov dictionary is 21, Sancinov 31 pages), and designs, since they contain in particular the translations of Italian and French terms.

The next attempt to create a dictionary is the Musical Glossary (first published in 1962) by Lucijan Marija Škerjanc, which also contains an encyclopedic section in addition to the dictionary. A similar attempt is a professionally designed and extensive manuscript of Adolf Gröbming, which contains about 4000 passwords and is partly an encyclopedic work.

There are also several general, non-specialized dictionaries, containing musical terms. Approximately 1500 musical terms can be found in the Dictionary

\footnotetext{
The list of articles is in the doctoral thesis from the mentioned author (Grazio 2017: 234)
} 
of Slovene Literary Language (which started to emerge in 1970), but they are occasionally incompletely explained, as a result of the nature of the above- mentioned dictionary. This is also the case with the Great Slovene Lexicon (2003, 2004, 2005). The Lexicon Music from the series of lexicons of the Cankarjeva založba, published in 1981, is not a dictionary work, but it is terminologically fairly exhaustive.

The most ambitious project, which is expected to systematically process Slovenian music terminology, is the Musical Terminology Dictionary, which contains 1061 terms and was published as a pilot bundle (musical instruments and performers) in 1983, but the work then stopped and has not continued until today.

The latest specialized musical dictionaries have been created over the past ten years. Perhaps the most comprehensive and ambitious is the Dictionary of Percussion Terminology which was released under the auspices of the ZRC SAZU in cooperation with the Slovene Percussion Project in April 2014. The pedagogue, percussionist and founder of the project Franci Krevh and the Marjeta Humar, a terminologist in the Terminological section of Fran Ramovš Institute of the Slovenian Language ZRC SAZU, have collected and covered the terms related exclusively to the field of percussion (instrument names, playing techniques, playing effects, etc.) from 634 dictionary entries. This dictionary is available on the website Terminologišče (https://isjfr.zrcsazu.si/sl/terminologisce/slovarji/ tolkalni\#v) and the portal Fran (https://fran.si/). The initiative for the production of narrowly specialized dictionaries usually comes from the users' side, which was also the case with the dictionary of organ expressions, which has been produced since 2010 by members of the Jarina Bohinj Society.

It is a seven-language (Slovenian-Italian-English-German-French-SpanishDutch) dictionary of terms from the field of organology and orthology. Unlike the Glossary of Percussion, the dictionary of organ terms is more modest in its design, since it only lists synonyms in all languages, without definitions and additional explanations on the use of terms, grammatical elements, etc. The glossary is available on the Euroterm website (http://www.evroterm.gov.si/slovar) and the Ars Slovenia project (http://arsors.org). Despite the fact that it counts 263 expressions, it is still treated under test mode. In 2011, the first modern specialized Croatian-Slovenian glossary of musical terms in the field of harmony and counterpoint was created by Jelena Panić Grazio. 


\section{Basic information about the corpus, methodology and research tools}

\subsection{Corpus}

The corpus used in our research work is: a) written, b) monolingual, c) specialized (it contains only the texts of textbooks, which are a musical analysis), d) comprehensive (it contains the entire texts, not only individual parts), e) synchronous (it contains only modern texts created over the last decade), and f) static (no new texts will be added). It contains 1,253,578 pop-ups and 979,457 words from 37 documents. Thirty-two graduate, master and doctoral theses ${ }^{4}$ dealing with musical morphology and musical analysis, published between 2009 and 2017 and five textbooks (Borota 2013, Osterc, Ukmar and Mihelčič 1961, Škerjanc 1966, Vrhunc 2009) have been used for the corpus. For the needs of the research, two additional digital corpora from Jelena Grazio, the first one dealing with musical theory from the 19th century to the present, and the second one with music analysis, were added as well. Such a modern-corpus approach has made the search for music theory concepts - their form and meaning - easier and more reliable.

\subsection{Methodology and research tools}

Before the analysis, a corpus of texts in a written form was prepared, scanned and converted into PDF format, afterwards to TXT format. The corpus was then syntactically marked and lemmatized using the JOS ToTaLe text analyzer tool (http://nl2.ijs.si/analyze), which supports lemmatization. In the analysis, only the lemmatized version of the corpus was used, since the corpus was uploaded on the website and analyzed online with the Sketch Engine, ${ }^{5}$ a multifunctional tool for analyzing texts.

\section{Basic musical terms in the Slovenian language}

We have conducted an in-depth analysis of six basic musical terms: note, tone, motif, figure, melody and musical form. They have been selected on account of

\footnotetext{
The exact list of authors and titles can be found at https://old.sketchengine.co.uk/auth/corpora/.

5 https://www.sketchengine.eu/
} 
their frequent use in musical and general literature and because of their vague and indefinite meanings.

For each term, the etymology of the word is explained, which is also an indispensable part of any music-terminological research. Hans Heinrich Eggebrecht, the founder of musical terminology, speaks about the necessity to know the etymology of the word that we are dealing with, in his pioneer study Studien zur musikalischen Terminologie, where from the very first beginning he cites five basic principles on which the research of musical terminology should be based. In his last, fifth principle it is stated: "The key to understanding the concept of a music is the knowledge of its etymological origin" (Eggebrecht 1955: 11).

As a relevant source of definitions of the terms considered, a basic, general dictionary, the Dictionary of the Slovenian literary language is selected. Given that the Slovenian language does not have a specialized musical terminological dictionary, the vast majority of users are employing (as a choice for searching terminology), either the accessible professional literature in Slovenian language (in the mentioned dictionary) or, in a terminological nest, where the password is treated as a term.

\subsection{Nota 'note'}

From an etymological perspective, the word nota is taken from the German word Note. The origin can be found in the Latin word for nota, which means "mark, sign, note, character, letter." In the Dictionary of Standard Slovenian (hereafter referred to as the SSKJ) the term note is defined as either a "tone sign" or "a tone marked by such a character."

\section{Results obtained from the corpus}

The term nota has 354 hits in 29 documents. The most commonly used multiword terms are menjalna note 'exchange note' (9), dolga nota 'long note' (17), zadnja nota 'last note' (12), zapisana nota 'written note' (5), zgornja nota 'top note'.

Only one definition is provided: "For the notation of music are used musical symbols, the most commonly used are note and pause. The note symbol in-

\footnotetext{
${ }^{6}$ https://fran.si/193/marko-snoj-slovenski-etimoloski-slovar/4289403/nta?FilteredDictionaryIds= $193 \&$ View $=1 \&$ Query $=$ nota

$7 \mathrm{http} / / /$ bos.zrc-sazu.si/cgi/a03.exe?name=sskj_testa\&expression=nota\&hs=1.
} 
dicates the pitch and duration of a sound" (Borota 2013). The musical symbol 'nota' (note) is often used in musical and metaphorical meaning.

\section{An example of metaphorical meaning}

"In the analysis of all the nine art songs of the cycle I will try to show how the music reflects the feelings and the atmosphere of individual songs, how the composer emphasized Heine's ironical and satire 'note' if he harmonized it, and how he managed to connect all the nine art songs into a meaningful cyclical form, not only in the content sense, but also in the musical sense" (Pangeršič 2016).

\section{Examples of the use in the sense of partitur (musical score)}

"In the madrigal, when looking at the notes, we see madrigalism,"... "eyes visible," because it uses a black notation (crochets and quavers) for the notation of 'lo moriro', and for the word 'Amore' it is white." (Gril 2016)

"He also took the recordings and notes (musical scores) of Slovenian works on the tour, along with the printed editions of his compositions, such as, for example, 'Good afternoon, Ciciban and Little Pianist'” (Gorenšek 2014).

An example of notes as musical symbols for the notation of music in partitur "Under the notes of the upper voice, there are slightly blurred signs that probably are not part of the musical notation" (Vončina 2009).

\subsection{Ton 'tone'}

The etymology of the word ton 'tone' is taken from the German word Ton, from Latin word tonus 'sound, tone, pitch, strain, tension', and borrowed from Greek word tónos 'rope, chord, tone', having a meaning also as "stress, stretch, tension." The SSKJ defines the ton as "sound of a certain height, duration, strength and color" and adds examples of "play, tune the tone; decrease, increase tone; long, short tone; loud, quiet tone; low, high tone; tone strength; a tone of eight tones." 9

\footnotetext{
8 http://fran.si/193/marko-snoj-slovenski-etimoloski-slovar/4226743/tn?FilteredDictionaryIds=193\&View $=1 \& Q$ uery $=$ ton.

9 http://bos.zrc-sazu.si/cgi/a03.exe?name=sskj_testa\&expression=ton\&hs=1.
} 
The word ton 'tone' appears 2065 times in 34 different documents. Commonly used multiword terms are pedalni ton 'pedal point' (150), zadnji ton 'last tone' (93), osnovni ton 'basic tone' (86), dolgi ton 'long tone' (82) and zvišan ton 'sharpened tone' (74).

One definition of ton 'tone' is provided: “"Ton' (tone) is a type of sound that can be determined by the following musical features: pitch, duration, loudness and color" (Borota 2013).

Some examples of the use of the term 'ton' (tone)

"All tones that sound simultaneously must be notated one below the other. In the case of dyads, we notate one tone next to each other" (Borota 2013).

"Quavers are dominating in the lower voice on the tone ' $\mathrm{D}$ '. Soon tone ' $\mathrm{C}$ ' is added and in the continuation the musical interval second is present" (Gorenšek 2014).

\subsection{Motiv 'motif'}

The term motiv 'motif' is taken from the German language (Motiv) with the same meaning as the Latin word Motivus, which means 'stimulus, reason for the movement, action'. Interestingly, the English version of the motiv - motif is taken from the French language. There is a difference in the use of the term motiv in English version (motif) and American version (motive). In the Slovenian literature we find a fairly clear division of the concept of 'motiv' (motif) and 'figura' (figure), where the figure is defined as a repetitive motif, which does not have the same rhythmic-melodic expression and meaning as a motif in melody (Borota 2013). In foreign literature, where the English language is used, this demarcation is less clear, where the figure is placed in the category of musical idea, defined as 'motif'. An interesting interpretation is the one of the term ostinato, which is in English also defined as a motif, which is repeated three times in succession.

Results obtained from the corpus

The term motiv (motif) appears 1614 times in 35 documents. Commonly used multiword terms are: ritmični motiv 'rhythmic motif' (16), osnovni motiv 'basic motif' (24), značilni motiv 'characteristic motif' (12), leitmotiv 'leitmotiv' (18), submotiv 'submotif' (13). 
A few definitions are provided for the term motiv (motif): "The motif is understood to be the smallest musical semantic unit whose sequence of tones is characteristic for the composition or its individual part" (Borota 2013); "The motif is the smallest independent rhythmically-melodic or meaningful unit. It represents the central musical thought, after which the song is most often recognized. It has one main emphasis and ends with an acordic tone (the exception is modern music)" (Borota 2013); "The motif is the shortest musical thought, it is a set of all those elements in music (rhythms, melodies, dynamics, and others) with which we express some musical imagination" (Ukmar 1961); "The motif is usually defined as the shortest characteristic musical thought, which is rhythmically, melodically and harmonically clearly and undeniably presented" (Škerjanc 1966).

The comparison with the definition of motif in the foreign dictionary of musical terms shows similar definitions, where the motif is also defined as a 'recognizable thematic part', a 'group of not having a recognizable thematic character'. ${ }^{10}$ With regard to the length of the motif, the Slovenian authors agree that there can not be only one (1) tone. As an exception, they mention Wagner and his work Rienzi. (A motif) usually contains two notes, more notes or one note and one pause. The length of the motif is often equal to one or two bars (Borota 2013); if it has more bars then the motif (usually) contains sub-motifs.

In the literature the length of the motif can depend on some language unit, for example, on one or two words or on a phrase (Borota 2013). According to Ukmar (1966) "it is not defined, how many tones and what kind of rhythmic - melodic group of tones should contain a motif." The English Dictionary of Musical Terms from Naxos states that "the motif is given as a figure." 11 An example of using a motif in a metaphorical sense as 'the main motif' as 'the main theme' or 'idea' is for example in the symphony (Osterc 1966).

\subsection{Figura 'figure'}

In the SSKJ, the term figura 'figure' is defined as a 'statue', 'image'. The term is assumed to be taken from the Italian figura, although we find the same word in

\footnotetext{
10 https://www.naxos.com/education/glossary.asp?char=M-O\#.

$11 \mathrm{Ib}$.
} 
German: Figur and in Latin figura, which also has the meaning 'shape, image'. In music, the term figura 'figure' is a "sequence of repeated tones." ${ }^{2}$

The etymological origin of the term figura ,figure' dates back to the 13th century, when the term figure is defined as the "visual representation of a person," late in the 14th century as "a visible and tangible form of everything," in the 15th century as "a body, in its entire form."13

Results obtained from the corpus

In the corpus, the term figura 'figure' appears 438 times in 35 documents. The most commonly used multiword terms are: ritmičn a figura/rhythmic figure (9), melodična figura/melodic figure (4), glasbena figura/musical figure (10).

The following definitions of the word figure can be found: "A repetitive motif that does not have the same rhythmic-melodic expression and meaning as a motif in melody" (Vončina 2009); "The motif is therefore primarily a melodic phenomenon, and the figure is 'chordic'. For both of them, it is understood practically by themselves that they have a specific rhythmic form, without which the music stream can not flow, be alive and fruitful"(Škerjanc 1966); "Each sequence of tones is not always decisive for the whole; conclusions, transitions and similar tone sequences have the task of concluding a piece or a part of it, connecting it, but not having the role of the basic building block. These less pronounced articles are in certain cases called figures and represent the opposite of the motif" (Vrhunc 2009).

The length of the figure is not clearly defined in the documents, except for its content, which can be rhythmic, "rhythmic in the sense that the shape of the figure is mostly preserved and that only a part of the melody pattern of the sample is changed" (Vončina 2009), and it can be melodic, which Vrhunc (2009) defines as "often repeated motif."

\subsection{Melodija 'melody'}

As a musical expression, the term melodija 'melody' is a combination of two concepts. If it is interpreted in the $\mathrm{MGG}^{14}$ with two different concepts as $\mu \varepsilon \dot{\lambda} \lambda o \varsigma$

\footnotetext{
12 http://www.fran.si/iskanje?FilteredDictionaryIds=130\&View=1\&Query=figura

13 https://www.etymonline.com/word/figure

14 https://www.mgg-online.com/
} 
'mode' and $\omega \delta \dot{\eta}$ 'song', then the interpretation of the original meaning of the first concept is less clear and is also interpreted as a noun (nominative, vocative and accusative in singular), as a 'limb of body', part', 'article', 'ingredient' (Kühn). In the SSKJ the term melodija 'melody' has three meanings: "A musical element based on successive relations between tones," "A publicistic expression, with the meaning of a short, usually pop song," and "A poetic expression," with the meaning of 'voices', 'sounds in general' (Hüschen 2016).

Results obtained from the corpus

The term melodija 'melody' appears 1693 times in 35 documents. Commonly used multiword terms are: koralna melodija 'choral melody' (419), ostinato melodija 'ostinato melody' (57), ljudska melodija 'folk melody' (31), celotna melodija 'complete melody' (30), glavna melodija 'main melody' (19), preprosta melodija 'simple melody' (17), različna melodija 'different melody' (10), enoglasna (znana) melodija 'homophonic (known) melody' (8), spevna/padajoča/vodilna/dolga melodija 'cantabile (falling/main/long) melody' (7), vzpenjajoča (značilna) melodija 'rising (characteristic) melody' (6) and ponavljajoča (variirana/ razgibana/neodvisna/ lepa) melodija 'repeating (diverse/independent/beautiful) melody' (5).

Only two definitions are found in the corpus, the first one is from Borota (2013): "Harmony, in addition to melody, rhythm and sound color, is the fundamental dimension of music." The second one is from Ukmar and Mihelčič (1961): "The second dimension in music is the melody. Every ordered, sequential group of different tones, notated with a note in a staff, is called a melody." There is no explicit definition for the term melodika 'melodic' that appears 66 times in the corpus.

The term melodija 'melody' is used with a musical and with peculiar metaphorical meanings as well. In the musical sense, it is used as a basic musical dimension (as it is used in the definitions from Borota and Ukmar and Mihelčič), with additional description of compositional or aesthetic characteristics. It is also used as a synonym for a song: "Between all the melodies, those with the fifth modus are the most similar, which may be associated with the (today understood) major chord, which represents the psalmodic intonation (as well as the initial phrase of the songs)" (Škorja 2011). Another example of melody in the sense of song: "Therefore, we are talking about evergreen melody songs by generations before us, at present (we sing some of them, too), and many of songs will probably be known to generations after us" (Cverlin Pušnik 2010). 
A few examples of melody with metaphorical meanings are given by the use of the adjective melodičen 'melodic', which appears 507 times in the corpus (of which 82 times in the tautological connection of words melodična linija 'melodic line'.

\subsection{Oblika 'musical form'}

As a musical expression, it is a superior term, which is used for all the structural units of the musical work (Hüschen 2016) or according to Kühn (2016): "The constructive or organizing element in music." The "umbrella compositional concept' is given to the musical structure in the thirties of the 19th century by Marx, who points out the interweaving of individual musical dimensions (and musical structure should cover more than the separate treatment of melody, rhythm, harmony and their interconnections).

Marx's understanding of musical structure, the new and last synthetic - poetic and receptive - compositional doctrine, was based on the assumption that in the creation of a music everything is allowed if it is based on some 'idea' or 'content' and everything is wrong and unacceptable if there are no solutions or meaningful ideas. Nevertheless, the concept of a musical structure often differs from the one that attaches to music certain 'contents', 'connotations', 'meanings' (content', 'idea'). Marx's musical structure includes the Greek terms morphe and eidos, which were combined in Latin as the term forma (Tatarkiewicz 1980). Both terms are important in Marx's musical structure, the content of the structure ('the inner, 'unlearnable') and the inseparable technical part ('the external', 'learnable'), which are 'the form of an artwork' and 'the statement of its content', ‘Äußerung seines Inhalts’ (Kühn 2016).

\section{Results obtained from the corpus}

The term oblika 'musical structure' appears 2532 times in 35 documents. Frequently used multiword terms are: pesemska oblika 'song's shape/structure' (305), sonatna oblika 'sonata form' (217), tridelna oblika 'three-part musical structure' (117), dvodelna oblika 'two-part musical structure' (96), sestavljena oblika 'combined musical structure' (79), osnovna oblika 'basic musical structure' (41) različna oblika 'different musical structure' (34), baročna oblika 'baroque musical structure' (31), nova/prehodna/variacijska oblika 'new (tran- 
sitional/variational) musical structure' (34/30/30), enodelna/enostavna/instrumentalna oblika 'one-part (simple/instrumental) musical structure' (27/27/26), simetrična/harmonična/melodična/svobodna/naravna oblika 'symmetric (harmonic/melodic/free/natural) musical structure' (24/23/23/21), prvotna/posebna/ tradicionalna/ciklična/spremenjena oblika 'original (special/traditional/cyclical/modified) musical structure’ (19/19/18/16/16).

There can be found only one - descriptive - definition: "The musical structure is characterized by the fact that it is based on the horizontal and vertical intertwining of the three basic musical dimensions: melody, rhythm and harmony" (Borota 2013). From the perspective of content, the term oblika ,musical form" refers to the entire composition, e.g. "the most common musical structure of a three-part song A-B-A" (Borota 2013).

\section{Conclusions and future work}

The research has shown that the expressions in the field of musical terminology were and still remain an exceptionally vibrant, evolving field of language, in which the creation of new expressions and morphological-semantic changes of the already existing expressions have persisted all the time. The results of this development are also seen in current music theory textbooks, among which there are discrepancies at the level of the use of a professional term. The same terms are often used in several varieties and with different meanings.

The purpose of this preliminary research was not only to get a deeper insight in the explored terms, but to contribute to the lowering of the "linguistic barrier". This barrier occurs when having different meanings for the same words and when it is difficult to find the right explanation for a term in the existing dictionaries, as they obviously cannot keep with the rapid evolution occurring in a language.

Although polysemy is a natural process, due to the fact that every expression connected with human activity is a living organism which constantly changes, it is necessary not to forget the principle that a terminological lexicon should be, as a rule, developed and created in accordance with conventions/norms, which, however, were so modest in the past that the authors of the textbooks were primarily inspired by other authors of textbooks. Systematic codifications in the 
form of a dictionary were not available. This has led to the fact that unsystematic engagement between authors and the issue of codification of terms, is still present in the digital age.

The present research could be extended to an in-depth analysis of the terms already discussed and to used resources as well. The analysis of the differences between terms from the perspective of those who are using them or for example, the differences between textbooks intended for music education in various institutions would certainly produce interesting results.

\section{References:}

Ars Organi Sloveniae: http://arsors.org (accessed 12 March 2018).

Bajuк, Marкo. 1926. Nekaj pevskega imenstva. Pevec 6/I-II. 5-8. http://www.dlib. si/?URN=URN:NBN:SI:DOC-9AQ7XYGP (accesed 5 May 2018).

Bajuk, Marko. 1926. Nekaj pevskega imenstva. Pevec 6/III-IV. 17-18. http://www.dlib. si/?URN=URN:NBN:SI:DOC-MW5LDMBK (accessed 5 May 2018).

Boden, Deidre. 1994. The Business of Talk. Polity. Cambridge.

Borota, Bogdana. 2013. Osnove teorije glasbe in oblikoslovja za učitelje in vzgojitelje. Univerzitetna založba Annales. Koper.

CVerlin PušNiK, ANJA. 2010. Primerjana uglasbitev besedil zmagovalnih skladb na festivalu Slovenska popevka v letih 1963 - 1968 ter 2003 - 2008. Diploma thesis. Faculty of Arts, University of Ljubljana. Ljubljana.

Dépelteau, François; Saviola Landini, Tatiana. 2013. Norbert Elias and social theory. Palgrave MacMillan. Hampshire.

EgGebrecht, Hans Heinrich. 1955. Studien zur musikalischen Terminologie. Akademie der Wissenschaften und der Literatur, F. Steiner. Wiesbaden.

ERČUlJ, ANa. 2013. Ljudska pesem iz Zagorice v Dobrepolju. Diploma thesis. Faculty of Arts, University of Ljubljana. Ljubljana.

Evroterm: http://www.evroterm.gov.si/slovar (accessed 28 March 2018).

GoRenšEK, JASNA. 2014. Komorna dela za klavir štiriročno Igorja Dekleve. Diploma thesis. Faculty of Arts, University of Ljubljana. Ljubljana.

Grazio, Jelena. 2017. Terminologija v slovenskih glasbenih učbenikih od leta 1867 do danes. Doctoral dissertation. Filozofska fakulteta, Univerza v Ljubljani. Ljubljana.

Gril, Ana. 2016. Luca Marenzio Razvoj šestglasnih madrigalov. Diploma thesis. Faculty of Arts, University of Ljubljana. Ljubljana. 
Homer, MiLko. 1994. Slovar glasbenih tujk. Gimnazija in srednja kemijska šola. Ruše. Hünschen, Heinrich. 1997. Melodie. MGG Online. Laurenz Lütteken, Kassel, Stuttgart, New York. https://www-mgg-online-com.nukweb.nuk.uni-lj.si/mgg/stable/28529 (accessed 21 May 2018).

JOS ToTaLe text analyzer tool: http://nl2.ijs.si/analyze

Kühn, Clemens. 1995. Form. MGG Online. Laurenz Lütteken, Kassel, Stuttgart, New York. https://www-mgg-online-com.nukweb.nuk.uni-lj.si/mgg/stable/14973 (accessed 21 May 2018).

MGG Online: https://www.mgg-online.com/(accessed 11 May 2018).

Mikkonen, YrJö. 2004. On Conceptualization of Music. Doctoral thesis. University of Jyväskylä. Jyväskylä.

Naxos Music Library: https://www.naxos.com/ (accessed 13 April 2018).

Nuyts, Jan; Pederson, Eric. Language and conceptualization. Cambridge University Press. Cambridge.

Omerzel-Mirit, Mira. 1999. Slovenska etnomuzikologija med preteklostjo in sedanjostjo: raziskovanje terminologije in razvoja "predklasičnih" ljudskih glasbil. Traditiones: zbornik Inštituta za slovensko narodopisje in Glasbenonarodopisnega inštituta ZRC SAZU. 153-165.

Online Etymology Dictionary. https://www.etymonline.com/ (accessed 22 April 2018).

Osterc, Slavko. Oblikoslovje I, Rkp. Kronika I. Glasbena zbirka NUK.

Oxford Music Online: http://www.oxfordmusiconline.com/

PAngeršIč, Tina. 2016. Schumannove uglasbitve Heinejeve poezije. Diploma thesis. Faculty of Arts, University of Ljubljana. Ljubljana.

Perseus 4.0: http://www.perseus.tufts.edu/hopper/

Sancin, Dušan. 1933. Glasbeni besednjak. Mohorjeva tiskarna. Celje.

Schomaker Spring, Margaret; Zaheer, Srilata. 2014. The role of language in knowledge transfer to geographically dispersed manufacturing operations. Journal of International Management, 20(1). 55-72.

SNOJ, MARKo. Slovenski etimološki slovar. www.fran.si (accessed 15 May 2018).

Slovar slovenskega knjižnega jezika. www.fran.si (accessed 15 May 2018).

ŠKerJanc, LuCiJAn MariJA. 1962. Glasbeni slovarček: v dveh delih: imenski-stvarni. Mladinska knjiga. Ljubljana.

ŠKerjanc, Lucijan Marija. 1966. Oblikoslovje. Državna založba Slovenije. Ljubljana.

ŠKorja, AljošA. 2011. Pesniški oficij svetega Nazarija. Diploma thesis. Faculty of Arts, University of Ljubljana. Ljubljana.

Tatarkiewicz, WŁadysŁaw. 1980. A History of Six Ideas: An Essay in Aesthetics. Kluwer Boston Inc. Massachussets. 
TrČen, Katarina. 2010. Orgelski opus Dietricha Buxtehudeja. Diploma thesis. Faculty of Arts, University of Ljubljana. Ljubljana.

Ukmar, Vilko; Minelčı̌, Slavko. 1961. Razvoj glasbe. Glasbene oblike. Državna založba Slovenije. Ljubljana.

Vončina, Ana. 2009. Conrad Paumann. Diploma thesis. Faculty of Arts, University of Ljubljana. Ljubljana.

Vospernik, HedviKa. 1995. Besedna komunikacija in uvajanje glasbene terminologije pri pouku na nižji stopnji osnovne šole. Glasbeno-pedagoški zbornik Akademije za glasbo v Ljubljani. Akademija za glasbo, Oddelek za glasbeno pedagogiko. Ljubljana. 92-93. VRBANČIČ, IVAN. 2010. Glasbeni slovarček. Mladinska knjiga. Ljubljana.

VRhunc, LARISA. 2009. Glasbeni stavek: Oblikoslovje. Znanstvena založba Filozofske fakultete. Ljubljana.

Whittall, Arnold. 2001. Form. Grove Music Online. EIC Root, Deane. http:// www.oxfordmusiconline.com.nukweb.nuk.uni-lj.si//grovemusic/view/10.1093/

gmo/9781561592630.001.0001/omo-9781561592630-e-0000009981 (accessed 21 May 2018).

Zadravec, Tina. 2013. Heinrich Ignaz Franz Biber: Skrivnosti rožnega venca. Diploma thesis. Faculty of Arts, University of Ljubljana. Ljubljana.

\section{Analiza slovenske terminologije glazbenih oblika}

\section{Sažetak}

Članak predstavlja rezultate analize upotrebe slovenske glazbene terminologije koja se koristi u pisanju o glazbenim oblicima. Budući da ova terminologija obuhvaća popriličan broj termina, odlučili smo se ograničiti na analizu sljedećih termina: melodija, ton, nota, oblik, figura i motiv. Za potrebe istraživanja na stranicama www.sketchengine. co.uk stvorili smo jednojezični korpus koji sadržava diplomske, magistarske i doktorske radove koji se bave glazbenom analizom te nekoliko udžbenika koji se bave glazbenim oblicima. Takav, suvremeni korpusni pristup, omogućio je lakše pretraživanje izraza i njihovih značenja, što nas je u konačnici dovelo do zanimljivih rezultata o načinu upotrebe pojedinih termina.

Keywords: terminology, musical structures, music theory, textbooks, corpus linguistics, Sketch Engine

Ključne riječi: terminologija, glazbeni oblici, glazbena teorija, udžbenici, korpusno jezikoslovlje, Sketch Engine 